sciendo

DOI: 10.2478/RAE-2019-0037 Review of Artistic Education no. 182019 330-340

\title{
7. USING THE TEXTBOOK WITH THE MUSICAL EDUCATION LESSON
}

Marina Morari ${ }^{314}$

\begin{abstract}
The present article identifies the characteristics of a good textbook, it analyses and describes some of the concepts used in the structure of the Musical Education textbook for the second grade in the Republic of Moldova. Some units of the textbook are classified and characterised in relation to the requirements of modern education. Also, the article describes working techniques with some of the contents: theme title, the interface text, the informative text, pictographic images.
\end{abstract}

Key words: musical education, working techniques with the textbook, specific skills, textbook content elements, interface text, informative text, pictographic images

\section{Introduction}

"The textbook is the work tool of the student and it must have an informative function, a learning structuring function and the function of guiding learning" [9], ensuring the valorisation of educational policies, conceptually, methodologically and praxiologically based on the Reference Framework of the National Curriculum [1]. The school textbook represents one of the work tools of students, based on building skills, detailing systematically the themes recommended by the curriculum and contributing to the organisation of the learning process. [4, p. 32].

A good textbook is "a work tool where information, didactic strategies, interactive didactic games, design, fonts, the graphic stylistics of the text, the correlation between the textual information and the iconographic information, the succession of informative texts, interactive activities, with the continuous participation of the student, the synthesis, extensions and self-evaluations - all together contribute to the shaping of personality, stimulate thinking and facilitate the creation of skills and competence and finally - as it will be obvious in the next stage - will form the necessary competences" [3, p. 8].

The concept behind the Musical Education textbooks for grades $1^{\text {st }}$ to $8^{\text {th }}$ (Stiinta Publishing House) was built during several decades, having as authors well known personalities in the fields of music and musical pedagogy and a team of specialists with expertise in the area of editing didactic books in accordance with the challenges of the times. The Musical Education textbook for the $2^{\text {nd }}$ grade (authors: M. Morari, A. Borş, E. Coroi, Stiinta Publishing House) approaches the contents from the perspective of modern paradigms

\footnotetext{
314 Associate Professor PhD., „Alecu Russo” State University from Bălţi, Republic of Moldavia, email: mmmorari@gmail.com
} 
focused on the student and on the skills, ensuring the correlation between assumed skills and offered contents.

In order to become an operational work tool for the students, teachers must adequately apply the working techniques with the textbook, depending on the priorities of the Curriculum for Primary School developed as follows: (a) in organising group and individual activities, (b) in facilitating the practice of independent and team work, (c) in the integrated approach to musical education, (d) in ensuring the inter- and transdisciplinary connections, (e) in forming the skills specific for each learning unit, (f) by intensifying student focused learning, etc.

\section{Discussions}

Students learn how to work with the textbook during the lesson during frontal, group or individual activities. Then, the student needs to learn some content from the textbook individually. The teacher discusses with the entire class in order to make sure that all students have assimilated the contents correctly, draws attention on the more important aspects, each student is observed, possible errors are corrected, lacks in students' knowledge are revealed and the work style and rhythm as well as the level of content absorption are ascertained. Of course, not every unit in the textbook is suited for individual study. Clearly formulated tasks which contain examples already applied in the classroom are most suited for individual study.

Creative use of the textbook can increase and emphasize the value of music in order to reach the specific competences. In order to understand the cover area of the specific competences through musical-didactical activities we suggest a list of good activities and contexts for the students' musical education, each being a direct component of the way each competence is formulated (see table below).

\begin{tabular}{|c|c|}
\hline Skills & Skill forming/developing activities and contexts \\
\hline $\begin{array}{l}\text { Understanding music } \\
\text { in learning and } \\
\text { everyday situations, } \\
\text { with an interest for } \\
\text { self-knowledge and } \\
\text { knowledge of the } \\
\text { world through the } \\
\text { arts. }\end{array}$ & $\begin{array}{l}\text { - Hearing, catching, living the music feeling, revealing artistic } \\
\text { sonorities, recognising melody/ rhythm/ type of melody ... } \\
\text { — Listening to, following, comparing/ contrasting, observing some } \\
\text { elements of expression, types of melody, etc. } \\
\text { — Auditioning, perceiving, organizing musical ideas, researching } \\
\text { the evolution of expression means ... } \\
\text { — Humming/ memorising musical themes, creating the listener's } \\
\text { melodic contour/ melodic gestures/ musicogram/ score ... } \\
\text { — Characterising image/ language expressivity, identifying } \\
\text { language elements giving expression to music, knowing and using } \\
\text { musical terminology ... } \\
\text { — Relating music to life, emotional identification with music ... } \\
\text { - Manifesting audition culture, interest for music, expressing } \\
\text { positive attitude for some musical creations ... }\end{array}$ \\
\hline
\end{tabular}




\begin{tabular}{|l|l|}
\hline & $-\begin{array}{l}\text { Vocal/ choral interpretation of a repertoire of songs, musical } \\
\text { themes from the auditioned creations. }\end{array}$ \\
$\begin{array}{l}\text { Expressing feelings } \\
\text { and ideas through } \\
\text { music, showing } \\
\text { creative attitude in } \\
\text { valorising musical } \\
\text { language elements }\end{array}$ & $-\begin{array}{l}\text { Melodic/ rhythmical improvisations using text, music, } \\
\text { instrumental music }\end{array}$ \\
& $-\begin{array}{l}\text { Modelling the interpretation plan for a musical image in a song } \\
\text { (dynamic shades, tempo, climax ...) }\end{array}$ \\
$\begin{array}{l}\text { Musical development for children with musical instruments and } \\
\text { pseudo-instruments }\end{array}$ \\
$\begin{array}{l}\text { Accompaning vocal/ choral interpretation with plastic } \\
\text { movements, dance movements, bodily percussion }\end{array}$ \\
$\begin{array}{l}\text { Transposing the } \\
\text { acquisitions in the } \\
\text { field in educational } \\
\text { and cultural-artistic } \\
\text { contexts, proving } \\
\text { respect for the values } \\
\text { of national and } \\
\text { universal culture }\end{array}$ & $-\begin{array}{l}\text { Reading on musical background } \\
\text { Establishing a musical repertoire for independent auditions }\end{array}$ \\
\hline $\begin{array}{l}\text { Integration into cultural-artistic activities through song, audition, } \\
\text { musical development, improvisation, dramatization ... } \\
\text { Active participation to cultural manifestations }\end{array}$ \\
$\begin{array}{l}\text { Knowledge of valuable musical creations belonging to the } \\
\text { patrimony of national/ universal culture }\end{array}$ \\
$\begin{array}{l}\text { Choosing an adequate repertoire for family/ school/ community } \\
\text { festivities } \\
\text { Manifesting vocal-choral song culture, audition culture, music } \\
\text { analytical culture }\end{array}$ \\
$\begin{array}{l}\text { Independent study of music } \\
\text { Popularising music in the school/ community environment ... }\end{array}$ \\
\hline
\end{tabular}

We must retain that most of the activities and contexts suggested in the table do not exhaust the list, but focus on their relating character, their ability to relate to life. The forming/ developing of musical knowledge and skills contribute to forming the competences: (a) interest for self-knowledge and of the world through the arts; (b) creative attitudes in valorising elements of language; (c) respect for the musical values of national and universal culture.

In compiling the musical education textbooks, authors need to strictly observe the specificity of artistic knowledge and the didactic logic of the educational - artistic process, the stages of progress in the presentation of the contents and the student-friendly drawings. The contents of the textbooks must be open to the new. For example, in the musical education textbook (2019 edition, Stiinta Publishing House), the textbook content elements offer various application possibilities, as follows:

$\rightarrow$ Conventional signs: (a) orient the student and teacher through the paths of knowing and understanding music with different types of activities (Listen to. View; Interpret. Execute; Meditate. Express your opinion; Remember. Apply); (b) simplify the visual perception of the contents included in the textbook; (c) increase the ratio between the theoretical and application content.

$\rightarrow$ The textbook content reunites all structural elements: the themes of the modules, small subjects and content units subordinated to them, materials for 
self-evaluation, repertoire for the pieces for audition, repertoire for additional songs.

$\rightarrow$ The content unit ,represents an information means by which the competence units projected for the given learning unit are achieved" [1, p. 9] and it respectively includes information, learning contexts, didactic tasks, pictographic images, etc. - information means (ordered by subject) by which the projected competence units, including transversal/ transdisciplinary competences are achieved. The content units are conceived in such a way as to cover the visual space of two pages, which facilitates the organisation of study. Each subject reunites:

- (a) informative material regarding: music laws, elements of musical language suggested for audition, musical image of the pieces in the national and universal repertoire, composers' creation and life, definition of some musical terms, etc.

- (b) note and graphic text of the didactic songs and exercises, with harmonic support to make the background (innovation element, included at the request of the teachers), all included in an attractive artistic frame, with coloured elements depending on the studied language elements. The author of the music and poetic text is indicated with all musical texts, together with the tempo, the text of the songs and creative didactic tasks;

- (c) pictographic images associated to learning situations/ generalising/ illustrating musical knowledge and experiences, to the study of language elements, to paintings of recognised universal value, to certain historic periods and events/ musical creations/ human activities etc.;

- (d) didactic tasks for activities in the field of audition, music interpretation and elementary music creation. The tasks are clearly and comprehensively expressed and can be done in the amount of time available;

- (e) topics complementary to the educational path, with suggestive and provocative titles to stimulate knowledge such as: „Find out more”, „Musical auditions repertoire", Footnotes to explain field specific terms, etc.

$\rightarrow$ The informative text immediately following the title of each theme: (a) concisely represents the main ideas in the developing of knowledge, in relation to the age/ intellectual possibilities of the students, (b) allows the establishment of relations between life and music, a link between personal musical experience and the content unit to learn, (c) can be valorised during the lead-in discussions, the introductory word for the musical audition/ interpretation activity, the generalising moment for musical-artistic experiences.

$\rightarrow$ The didactic task for various musical - didactic activities by which the learning situations are built and organised and the progressive execution of the competence units is ensured. We must mention that each topic suggests learning tasks which ensure an optimal balance between theoretical and application approaches, observing the learning process based on articulating all psychological functions of the student (sensitivity, attention, memory, 
imagination and thinking). The didactic tasks are oriented towards the development of students' creativity and offer real application possibilities in the classroom and independent activities.

From the integration pedagogy perspective, a textbook must first follow the functions for the development of musical skills/ competences and support the integration of the students' acquisitions through the tasks it suggests. In this context, Gerard \& Roegiers [9] suggest a textbook that can focus the following functions:
A. Transmission of knowledge,
B. Forming skills and competences,
C. Consolidating acquisitions (knowledge, skills and competences),
D. Evaluation acquisitions,
E. Support for acquisition integration,
F. Reference,
G. Social and cultural education.

All content elements suggested in the textbook, including the musical repertoire and didactic tasks, must comply with these functions. The teacher is free to choose the techniques which contribute to reaching the objectives in a more effective manner. We also mention the fact that the techniques of using the textbook must valorise gradually the students' psychological - physiological characteristics. We further suggest techniques of using the textbook for various content elements: theme title, interface-text, informative texts about composers and musical creation, pictographic images, didactic tasks.

3. Techniques of working with the theme tile. The theme title is formulated in a concise and clear manner, often as a question. It is not compulsory to announce the theme at the beginning of the lesson. One or two key words are contained in the formula of each theme and they direct knowledge on a certain path. In order to become aware of and consolidate musical knowledge and knowledge about music, the following techniques can be practised:

$\delta$ - Poster image. Students make the poster individually or in pairs. The poster is a way to present communication. The theme title may be followed by the expressions: in my life/ in our lives/ in my family/ in my village/ in the life of my people. Thus, we can generate the following poster titles: "Music in my life/ in my family/ in the life of our school »; "Song diversity in the village/ nation life »; "Dance music in a man's life », etc. it is important to mention that the information on the poster can be organised as a spider and instead of answers/ informative texts we could use images, drawings, photographs, postcards. Making the poster may take one or two weeks, before or after the end of the unit and it can be used as evaluation.

$\delta$ - The cube. It is a method that allows learning by cooperation. The Cube Technique is used when we want to explore the theme from several perspectives. Questions are written on the sides of a cube made out of 
cardboard. The cube is randomly thrown to/ towards a student, who reads the question out loud. The teacher develops the question formula. There are several sets of tasks/ questions which may be written on the cube sides. The first example: what? how? how much? which? why? in what way? The second example: describe, compare, associate, characterize, enumerate, argument. The humming/ singing of musical themes may be used with this technique.

4. Techniques of using the interface-text. Each theme suggested in the textbook is followed by a short informative text, made up of 3-8 sentences, which unveils the main lines of musical laws in close connection to life. This text may be used creatively in order to generate the main ideas regarding the theme and to facilitate students' communication. We suggest the following techniques:

$\delta$ - „Idea Yarn”. The teacher asks students to carefully listen to a story and when a break occurs, students must be ready to continue the story with their own ideas. The student who raised their hand continues with the story as teacher may instruct him with an assertive gesture. The condition for this technique is to respect the continuity of ideas. For example, we suggest a few pilot ideas and some associate idea alternatives provided by the students:

\begin{tabular}{|l|c|}
\hline \multicolumn{2}{|c|}{ Example: Interface-text «What is music?» on page 5 of the textbook [7] } \\
$\begin{array}{c}\text { Pilot-ideas of the } \\
\text { interface-text stated by } \\
\text { the teacher: }\end{array}$ & Associated ideas suggested by the students (possible): \\
\hline $\begin{array}{l}\text { Music is the art of } \\
\text { sounds, created by }\end{array}$ & $\checkmark$ When we hear sounds we may ask if there is any music. \\
people. & $\checkmark$ Music lives only when it sounds and it is interpreted, heard. \\
& $\checkmark$ People create music differently because they live in different \\
& times, different countries. \\
\hline There is folk music and & $\checkmark$ Folk music and professional music are different. \\
professional music. & $\checkmark$ Each nation has its own folk music. \\
& $\checkmark$ Folk music is most common and easy to listen to. \\
& $\checkmark$ Professional music can be heard in concerts, on TV, in halls \\
\hline Folk music is composed & $\checkmark$ Folk music is sung and played using traditional instruments. \\
by anonymous creators, & $\checkmark$ Folk music is the most common type of music. \\
professional music by & $\checkmark$ Folk music is made up of songs, dances and traditional \\
composers. & marches. \\
& $\checkmark$ Professional music has its own musical genres. \\
\hline Composers & $\checkmark$ There are composers who created music known worldwide. \\
continuous inspiration & $\checkmark$ Composers write music following certain rules. \\
from folk music - & $\checkmark$ Anybody can write simple melodies. \\
necessary source of & $\checkmark$ You must attend music school in order to become a \\
inspiration. & composer. \\
\hline
\end{tabular}


$\delta$ - „Curious questions”. The teacher prepares a lsit of questions based on the interface-text. The questions may be listed separately on a card or grouped 3-4 questions on a card for group work. The class may be divided into 4-6 groups. Each group receives a card with a question or some questions based on the text they are about to listen to. After the teacher presents the story, each group tries to answer the questions and build their own story based on their answers. The presentations made by the groups may be followed by musical auditions or by singing of songs students have studied. Thus, we establish a connection between the ideas of the interface-text and the musical experiences of students. At the same time, students become aware of the musical rules, they enter debates and learn how to talk about music. Examples of questions based on the interface text Music and movement on page 42 in the textbook: «Many things around us are continuously moving. The art of music has various possibilities to express movement. For example: train movement, sound of horses running, the buzzing of the bumblebee and others. We very often recognise musical sounds that remind us of various movements in nature: the sound of the howling wind, the sound of water springs (water flowing), the rattling sound of leaves moving in the forest, etc. Various sonorities can be imitated in musical creations»».

Examples of questions:

- Why is the world we live in sonorous ?

- How do we distinguish the sounds around us? (high - low, noise - music, strong - faint, muffled - discordant, long - short, etc.)

- What can sounds around us communicate? (feelings, ideas, information, etc.)

- What characteristics do musical sounds have? (pitch, duration, intensity, timber)

- Which characteristics of the musical sound/ element of musical language help express movement? (intensity, tempo, etc.)

- How does sound express the movement of wind, birds' flight, train movement?

$\delta$ - „Euterpe's guests”. Two students in the class receive a special task and the interface-text during the next lesson. On their own initiative, the students may explain unknown vocabulary to the class (using the dictionary). Independently, students decide who and what is to be communicated based on the text. The other students in the class will find out who Euterpe's guests are during the next class. At the end of the story, each of the students will tell the class who was the most interesting/ most curious, which idea is very important, etc. The students' presentation "Euterpe's guests" is integrated by the teacher into the lesson scenario at the most convenient time to ensure emotional dramaturgy. At the end, the students receive their colleagues'/ teacher's appreciation and Euterpe's appreciation, which can be expressed by a note containing quotations about music, an idea about the role of music in people's lives and useful advice on optional auditions. It is important for each student to be Euterpe's guest over the length of one year and that the content of Euterpe's appreciation notes should be 
different each time. Here, the teacher may include appreciation and advice depending on the level of interest in music of each student.

$\delta$ - „Crosswords". The interface-text may be used as material to evaluate knowledge in the process of solving a crosswords puzzle (a genre using images to represent words or parts of words), crosswords grids in which concise definitions are contained in the squares separating the squares for the letters forming the words, or classical crosswords - one of the most common types of mental exercise in the world (a square or rectangular grid, where the purpose is to fill in with the blank spaces so that the horizontal and vertical lines form words). For this, the teacher will suggest the definitions of the words to be guessed. This must be organised as a frontal activity, with all students in the class participating or as group work. To this end, each group will have to solve a different alternative of the crosswords. It is important to formulate the definitions/ questions for each word in a clear and concise manner. The textbook also suggests the crossword technique with the «Self-evaluation» part at the end of the module.

\section{Working techniques with the informative texts about composers and} musical creations. For each musical creation suggested for study, the textbook presents short texts about their authors together with their portrait and the birth and death years. We advise teachers not to announce the birth and death years of the composers at the beginning of the class when the information about the composers has not been transmitted yet as the students have not yet been familiarised with their music through audition (analysis) and with details about the life and activity of the composer. This is why announcing the death year of the artist does not inspire and motivate the student to study his musical creations. It is better to focus on what the artisi gave to the world and to point out what distinguishes the composer from other composers and on his interest in music. Each text included in the textbook can be filled in and developed by the teacher within a certain time limit so that students are motivated and their interest in music increased. The informative text about the composer and musical creation is integrated into the musical audition activity and it is logistically subordinated to the theme.

$\delta$ - The mixed technique - one of the most accessible working techniques with the informative text as it combines verbal methods (storytelling, description, and characterisation) with the illustrative method, the example method, definition, graphic representation, etc.

$\delta$ - „The idea chain" technique. The storytelling method lies at the base of this technique, which has both formative and informative characteristics. The text in the textbook is told in the following manner: each idea in the text is told by a student. In order to create the idea chain the speaker transmits the right to continue the story to one of their colleagues by transmitting a bell (or any other object symbolical in the field of music). The teacher may start the story (with 
some unknown information) and continued by 5-8 students. Thus, students assimilate various information and they satisfy their need of knowledge and affectivity at the same time, stimulating their imagination and exercising their capacity to communicate. The text may be enriched with new ideas, from other sources. This techniques develops the following mental processes in the students: (1) language - as the fundamental means of communicating and receiving information; (2) logical thinking - due to the logical succession of events in the story; (3) voluntary memory - by retaining the unfolding of events and expressing them based on specific procedures and means; (4) imagination by creating new images based on working with representations and cognitive experience. In case the student cannot express and idea from the text, the teacher may formulate a helping question.

$\delta$ - The question technique allows the building of a didactic dialogue. The teacher can prepare a list of questions based on the texts in the textbook by which they can organise an active learning activity. In order to answer the questions, students can be guided to use various materials on the pages of the textbook. It is important to accept the question as an inevitable moment of the mental activity. "The question lies at the border between knowing and not knowing and can actively intervene in a learning situation.» [2, p. 142]. It can be applied to all types of informative texts, including definitions, knowledge about musical reading and writing, the «Find out more» section, and footnotes, etc. The way to organise such an activity: 1 . The teacher asks the first question. Students answers. With a partial answer, the teacher comes with additions and new information, explanations; 3. The teacher asks the second question. 4. Students answer. If the answer is partial, the teacher intervenes with useful information, etc.

The character and the range of questions can condition the construction of heuristic knowledge. Various types of questions, different as regards their contents and expression, direct differently and activate various levels of mental activities. For example: 1. What music can be considered march? 2. In what moments in somebody's life can we hear marching music? 3. Enumerate the names of the most common marches. 4. Which elements of musical language add expressivity to marches? 5. Name the traits characterising all marches, distinguishing marches. 6. Which characteristics can the music of a sports march/ military march/ festive march express? etc.

For the questions technique, it is relevant to use various types of questions [2]: with reproduction function, mnemo-technical questions appealing to memory (of the type: what is ? which are ? enumerate/ name which are ...); cognitive-reproductive questions (of the type: what is? what are? what? who? when?); cognitive-productive questions (of type: why?) ; convergent questions, which lead to analysis, comparisons, synthesis, data integration, idea associations, explanations. etc. ; divergent questions, which exercise thinking on new, original trajectories, involving multiple answers ; evaluation questions, 
which require issuing own judgement on a phenomenon (artistic/ valorising judgement).

The textbook offers a wide range of pictographic images, which can be associated to certain learning situations/ generalising/ illustrating musical knowledge and experiences, the study of language elements, informative texts, etc. Some images illustrate historic events and periods/ musical creations/ human activities, etc. We suggest a few techniques of using the pictures in the textbook, with the learning path built as it follows: (a) from picture to musical sensations/ experiences; (b) from pictures to generalising their own musical experiences/ knowledge about music; (c) from picture to musical interpretation; (d) from picture to identifying musical expressivity; (e) from picture to the learning situation/ adequate use of musical terminology in the creation process and characterisation of the music; (f) from picture to creating a representation on the way music is interpreted, etc. This means that the pictures included in the textbook can be creatively included in the organisation of various didactic tasks. When students do not succeed in accomplishing the didactic task, the teacher will bring the necessary explanations by which lacks in the students' understanding are eliminated. To this extent, the form, colour, size, position, composition etc., as criteria of characterisation of the elements included in the image, will become filters to stimulate sensitivity, attention, memory, imagination and, possibly, students' thinking in the process of visually receiving the image in relation to one of the musical-didactic activities.

All the techniques of using the textbook are good. The learning process requires an "application" activity that goes beyond the information provided directly on the textbook pages. All content elements in the textbook can have an informative and a formative role in the learning - teaching - evaluation process. The choice of an adequate method is one of the priorities of the lesson project, by which we ensure that students have processed the material and have developed their own understanding of music. Extraordinary possibilities can be created by overlapping the information in the textbook with everyday life by establishing/ identifying the relation of music to life, the relation between the student's experience and the musical phenomenon.

6. In conclusion, the working techniques with the textbook must: (1) support acquisitions integration in situations different from the ones met during the learning process; (2) act as reference, i.e. represent a source of information for the student - his landmarks for his musical ction/ activity; (3) form/ develop the musical culture of students as integral part of their spiritual culture and it refers to their acquisitions in terms of behaviour, human relations, life in society, in general. 


\section{References}

1. Cadrul de referință al Curriculumului Național. Aprobat la Consiliul Național pentru Curriculum (05.30.2017). Ministerul Educației, Culturii și Cercetării al RM, Chișinău 2018. - 73 p.

2. Cerghit Ioan (2006), Metode de învățământ. - Iași: Polirom.

3. Ciobanu Mircea (2016), Manualul naţional: avem noi oare manuale şcolare de calitate? Policy Brief Sinteză de politici în domeniul educaţiei, Institutul de Politici Publice, Chișinău.

4. Falk Pingel (2010), UNESCO Guidebook on Textbook Research and Textbook Revision. - Paris/ Braunschweig.

5. Gérard, F-M. et Roegiers, X. (1994), Concevoir et évaluer des manuels scolaires. Bruxelles : De Boeck-Wesmäel. Revue des sciences de l'éducation, 20(2), 1994, p. 399

6. Ghid de implementare a Curriculumului Naţional pentru învăţământul primar. Aprobat la Consiliul Naţional pentru Curriculum (Ordinul Ministerului Educației, Culturii și Cercetării nr. 1124 din 20 iulie 2018). MECC al RM. Chișinău, 2018.

7. Morari M., Borș A., Coroi E. (2018), Educaţie muzicală: Manual pentru cl. a 2-a. Min. Educaţiei al Rep. Moldova. - Ch.: Î.E.P. Ştiinţa.

8. Talpă Adela, Gîsca Nadejda (2009), Dosarul pedagogic - o necesitate ori o provocare?//Revista Economica, nr. 5(69), 2009. - Chișinău: ASEM, p. 14-18 9. Xavier Roegiers (2010), Manualul şcolar şi formarea competenţelor în invăţământ, accesat: https://ru.scribd.com/document/16646130/Manualul$\%$ C5\%9Fcolar-\%C5\%9Fi-formarea-competen $\%$ C5\%A3elor-ininv $\%$ C4\% $83 \%$ C $5 \%$ A3\% $4 \% 83$ mant 